\title{
Practical Recommendations for the Topical Treatment of Atopic Dermatitis in South and East Asia
}

\author{
David Luk · Kam Lun Ellis Hon • Maria Victoria C. Dizon • \\ Kin-Fon Leong · Yong-Kwang Tay · Mark Jean-Aan Koh • \\ Nisha Suyien Chandran · Siriwan Wananukul · Susheera Chatproedprai · \\ Thomas Luger
}

Received: September 30, 2020 / Published online: December 12, 2020

(c) The Author(s) 2020

\section{ABSTRACT}

Introduction: There is some evidence to suggest that the prevalence of atopic dermatitis (AD) in Asia is rising. We have therefore developed an algorithm for the topical treatment of AD throughout South and East Asia for use by primary care physicians, pediatricians and dermatologists.

Methods: Nine AD experts from South and East Asia and one from Europe developed the algorithm based upon treatment guidelines, relevant literature and local treatment practices.

D. Luk

Department of Paediatric and Adolescent Medicine, United Christian Hospital, Kwun Tong , Hong Kong SAR, People's Republic of China

K. L. E. Hon

Department of Paediatrics, The Chinese University of Hong Kong, Hong Kong SAR, People's Republic of China

M. V. C. Dizon

Department of Dermatology, University of Santo

Tomas, Manila, Philippines

K.-F. Leong

Kuala Lumpur General Hospital, Kuala Lumpur, Malaysia

Y.-K. Tay

Department of Dermatology, Changi General

Hospital, Singapore, Singapore
The algorithm outlines current best practice for the use of emollients, topical corticosteroids (TCS) and topical calcineurin inhibitors (TCI), with the intention of simplifying the treatment regimen of mild-to-moderate AD in South and East Asia.

Results: Patients with AD should bathe and cleanse affected skin to remove crusts and scales daily. Emollients should also be applied daily as a maintenance treatment. When selecting appropriate topical anti-inflammatory treatment for AD flares, several factors should be taken into consideration, including the patient's age, attitude to treatment options and site of $\mathrm{AD}$ lesions. Given the concerns regarding

\section{J.-A. Koh}

Dermatology Service, KK Women's and Children's Hospital, Singapore, Singapore

\section{N. S. Chandran}

Division of Dermatology, Department of Medicine, National University Hospital, Singapore, Singapore

S. Wananukul $\cdot$ S. Chatproedprai Department of Pediatrics, Faculty of Medicine, Chulalongkorn University, Bangkok, Thailand

T. Luger $(\bowtie)$ Department of Dermatology, University of Münster, Münster, Germany e-mail: luger@uni-muenster.de 
the risk of skin atrophy with use of TCS, a TCI should be used to treat $\mathrm{AD}$ lesions in sensitive skin areas: pimecrolimus is recommended for mild-to-moderate $\mathrm{AD}$ in these locations, while tacrolimus should be considered for moderate and severe cases. Either pimecrolimus or tacrolimus is recommended for flares in other, nonsensitive body locations. A proactive or intermittent maintenance treatment strategy involving regular emollient use and twiceweekly application of a TCI to previously affected areas is encouraged to reduce the risk of flares.

Conclusions: The algorithm proposed here is intended to simplify the topical treatment of mild-to-moderate AD in daily practice in South and East Asian countries.

Keywords: Algorithm; Atopic dermatitis; Pimecrolimus; South and East Asia; Tacrolimus

\section{Key Summary Points}

Atopic dermatitis (AD) is a chronic, relapsing, inflammatory skin disease that appears to be increasing in prevalence in Asia, indicating an urgent need for effective treatment strategies.

We have proposed a practical algorithm to simplify the topical treatment of mild-tomoderate $\mathrm{AD}$ in adult and pediatric patients in South and East Asian countries, with a focus on the role of topical calcineurin inhibitors (TCI).

The algorithm emphasizes the importance of sensitive skin areas and is intended for use in daily clinical practice by primary care physicians, pediatricians and dermatologists.

Pimecrolimus is recommended to treat mild-to-moderate $\mathrm{AD}$ affecting sensitive skin areas, while tacrolimus should be considered for moderate and severe cases; either pimecrolimus or tacrolimus is recommended for flares in other, nonsensitive body locations.
A proactive maintenance treatment strategy involving the twice-weekly application of a TCI and regular emollient use to previously affected areas may reduce the risk of a recurrence of disease flares.

\section{DIGITAL FEATURES}

This article is published with digital features to facilitate understanding of the article. You can access the digital features on the article's associated Figshare page. To view digital features for this article go to https://doi.org/10.6084/m9. figshare.13194935

\section{INTRODUCTION}

Atopic dermatitis (AD) is a chronic, relapsing, inflammatory skin disease $[1,2]$, which is believed to exhibit distinct etiological differences between Caucasians and Asian races. For example, clinical studies have shown an increase in interleukin-17 (IL-17)-producing cells in Asian patients with AD and a predominance of the psoriasiform phenotype compared with Caucasian patients with AD [3]. The prevalence of $\mathrm{AD}$ varies across Asia. Children in Singapore have an AD prevalence of $20.6 \%$, nearly twice that of Singaporean adults (11.1\%) [4]. In Malaysia, the overall prevalence of childhood $\mathrm{AD}$ is $13.4 \%$, and it is most common in Malays, males, children aged $<2$ years, and those with an atopic background, such as asthma, hay fever, and family history of atopic diseases [5]. A study using Korean national statistics gathered from health insurance data reported that the prevalence of $\mathrm{AD}$ in 2008 ranged from $26.5 \%$ in 12 - to 23 -month-old infants to $2.4 \%$ in 18 year olds [6]. An investigation of trends over time (1990-2010) in international prevalence of $\mathrm{AD}$ suggests that $\mathrm{AD}$ is becoming more prevalent in East Asia [7]. However, the prevalence of AD in Singapore has plateaued at about one in five children when figures published in 2002 and 2018 are compared $[4,8]$. 
The prevalence of $\mathrm{AD}$ varies between urban and rural areas, suggesting that environmental factors, such as air pollution, are significant contributors to the epidemiology of AD. Indeed, a recent study has shown that air pollutants found in urban areas, such as diesel exhaust particles, can trigger hyper-innervation and pruritus, leading to the development of $\operatorname{AD}[9,10]$.

Genetic factors may also influence the epidemiology of $\mathrm{AD}$ in Asia, as illustrated by mutations of the filaggrin gene in Chinese populations, which differ from those present in European populations $[11,12]$. For example, the c.3321delA filaggrin gene mutation is associated with clinical phenotypes of $\mathrm{AD}$ in the Chinese Han population, but is absent from European populations [12].

The treatment paradigm for mild-to-moderate $\mathrm{AD}$ is based on emollients, topical corticosteroids (TCS) and topical calcineurin inhibitors (TCI). Systemic immunosuppressive agents and phototherapy are typically reserved for more severe or refractory cases. However, slight geographical variations in prescribing practices exist across Asia. A survey of 255 dermatologists across Singapore, Malaysia, Indonesia, Thailand, Vietnam, and the Philippines found that most used mild-to-moderate potency TCS, but that there was a tendency in Vietnam and the Philippines to reserve TCS for severe cases in infants and children [13]. Similar variations were observed in the use of TCI [13].

Complementary and alternative medicines, such as herbal preparations, are used by many patients in China, Taiwan, and other Asian countries, either alone or in combination with licensed products $[14,15]$, although evidencebased data from randomized controlled trials are lacking $[14,16,17]$, and the extent of their role in the management of $\mathrm{AD}$ in Asia is not clear. Integrative medicine (the combination of western medicine and Chinese medicine) may be useful in the treatment of $\mathrm{AD}$ but determining this will require collaboration between practitioners from each discipline [17].

$\mathrm{AD}$ often affects areas where the skin is thin and sensitive, such as skin flexures and the face. A naturally thin stratum corneum in these areas makes them prone to epidermal barrier dysfunction and transepidermal water loss, and hence to the development of AD. Thinner skin is also more permeable to irritants, leading to more frequent flares, and is particularly vulnerable to steroid-induced atrophy [18]. Thin skin areas therefore require special consideration in the management of $\mathrm{AD}$ and may benefit from steroid-sparing treatment strategies.

Here we discuss steroid-sparing treatment strategies and also consider situations in which patients may benefit from steroid-sparing treatment, such as when they are reluctant to use TCS due to concerns over skin atrophy and other potential side effects. Such "corticophobia" is increasingly recognized as a significant factor contributing to poor TCS treatment adherence [19]. We also propose a practical algorithm for the topical treatment of mild-to-moderate $\mathrm{AD}$ in both adult and pediatric patients in daily clinical practice in South and East Asia. The algorithm has been structured for use by primary care physicians, pediatricians, and dermatologists. We aim to supplement, rather than replace, more detailed evidence-based international and national treatment guidelines, with a focus on the role of TCI in the treatment of mild-to-moderate AD.

\section{METHODS}

An international panel of nine experts in $\mathrm{AD}$ from Asian countries, including Hong Kong, Singapore, Malaysia, the Philippines, and Thailand, and one expert from Germany, was formed to develop an algorithm for the topical treatment of $\mathrm{AD}$ in daily clinical practice in South and East Asia. The panel included dermatologists and pediatric specialists. The first draft of the algorithm was proposed by one of the authors, Thomas Luger, which was then discussed with the other authors and adapted to South and East Asia based on their expertise, local knowledge, guidelines [20-26], and relevant literature. The first draft of the algorithm proposed by Professor Luger has also been adapted for the Middle East by a separate group of experts from the Middle East region [27].

This article is based on previously conducted studies and does not contain any studies with human participants or animals performed by any of the authors. 


\section{Proposed Treatment Algorithm for Mild- to-Moderate AD in South and East Asia}

The proposed new AD treatment algorithm, which emphasizes the importance of sensitive skin areas (applicable to both adult and pediatric patients), is outlined in Fig. 1.

\section{Diagnosis and Initial Assessment of AD}

The initial assessment of patients presenting with $\mathrm{AD}$ should take into account the patient's age and the site and severity of lesions (Fig. 1), since these factors may help determine the most appropriate treatment. Patient history may help to identify potential triggers (e.g., detergents, clothing, tobacco smoke, weather extremes, air pollution, food and environmental allergens) [28] that may precipitate the onset or flaring of $\mathrm{AD}$.
Exploration for a potential food allergy may be an important aspect in the identification of triggers, particularly in infants and young children in whom reported rates of food allergy range from approximately one-third to twothirds of children with AD [29]. Food allergens, including milk, eggs, soy, wheat, and peanuts, are among those commonly linked to exacerbation of $\mathrm{AD}$ [23]. If food allergy is suspected as a trigger, this should be investigated by measurement of immunoglobulin E (IgE) antibody levels and skin prick tests [23]. The diagnosis of food allergy should be confirmed by oral food challenge since eczematous reactions are often delayed and do not occur via the same mechanism as the immediate IgE-mediated response detected by a skin prick test [23]. Suspected allergens should be temporarily eliminated (e.g., for a period of 4-6 weeks) [23]; confirmed food allergies should be managed in partnership with a pediatric allergist. When the food containing the suspected allergen is gradually

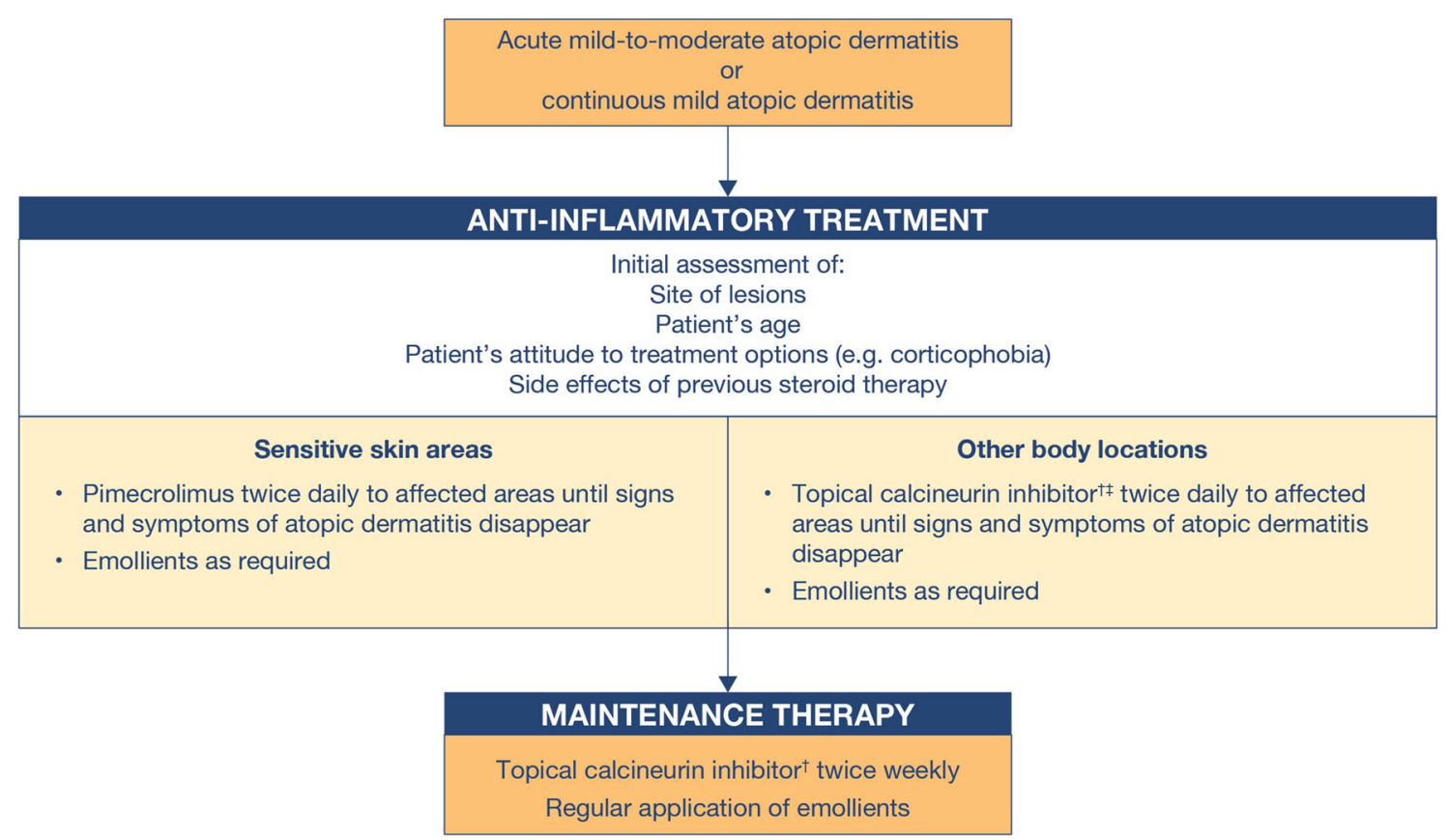

Fig. 1 Algorithm for the treatment of acute mild-tomoderate atopic dermatitis $(\mathrm{AD})$ or continuous mild $\mathrm{AD}$ in children, adolescents, and adults in South and East Asia. Single dagger superscript $\left({ }^{\dagger}\right)$ indicates topical calcineurin inhibitors (TCI): pimecrolimus $1 \%$ cream, or tacrolimus $0.1 \%$ (aged $\geq 16$ years) or $0.03 \%$ (aged $2-15$ years) ointment; pimecrolimus is not indicated for severe $\mathrm{AD}$ and tacrolimus is not indicated for mild AD. Double dagger superscript $\left({ }^{\ddagger}\right)$ indicates use of topical corticosteroids (TCS) that should be reserved for severe disease flares, but brief treatment with TCS may be considered if inflammation persists despite treatment with TCI 
reintroduced, the status of the patient's skin should be assessed before and $24 \mathrm{~h}$ after oral food challenge [29]. The initial evaluation of a patient presenting with $\mathrm{AD}$ may also include assessment of the impact of AD on the patient's quality of life, daily activities, sleep, and psychosocial wellbeing, and whether lesions appear infected.

\section{Maintenance Treatment with Emollients}

The cornerstone of $\mathrm{AD}$ management is regular use of emollients, with the aim to maintain skin hydration and reduce water loss due to epidermal barrier dysfunction [22, 23, 30]. An ideal emollient should contain a combination of occlusive agents to slow down water loss, humectants to increase capacity to withhold moisture, and lubricants to reduce friction against skin [31]. Many emollients are available, including aqueous lotions, water-in-oil or oilin-water creams, and oil-based ointments [23]. There is no evidence for superiority of any one type of emollient over others [14, 31], therefore the choice of emollient may depend on local availability, cost, patient preference, and the physician's recommendation [31].

Selecting an appropriate emollient may involve an element of trial and error to identify the most suitable maintenance treatment for an individual patient. Preparations containing sodium lauryl sulphate are not recommended for regular use as emollients. Daily showers or baths with tepid or luke-warm water and soapfree washes or soap substitutes are recommended, especially to remove crusts or scales. A leave-on emollient should then be applied immediately after bathing to maintain hydration [14, 23]. In addition, if there are visible signs of inflammation, topical anti-inflammatory agents should be applied to the affected areas (see below) [22, 23].

\section{Anti-inflammatory Treatment}

The interplay of skin barrier defects, immune abnormalities, the microbiome, and environmental triggers appears to promote inflammatory responses involving $\mathrm{T}$ cells, chemokines, and cytokines. These inflammatory responses lead to the characteristic pruritic flares of $\mathrm{AD}$ $[1,32-35]$. Topical anti-inflammatory treatments are therefore an integral part of the management of AD and include two predominant classes: TCS (numerous different agents with a range of potencies) and TCI (tacrolimus and pimecrolimus). The topical anti-inflammatory agents available for the treatment of $\mathrm{AD}$ in Asia are summarized in Table 1 [22, 23, 36-49]. While these are often used to control acute flares, the value of proactive anti-inflammatory treatment during periods of remission to prevent recurrence of flares, is increasingly recognized [37].

TCS are regarded as first-line therapy for acute flares $[2,23]$ and play an important role in the management of $\mathrm{AD}$ in Asian patients when used appropriately [22]. Indeed, the recent Asian Academy of Dermatology and Venereology Expert Panel on Atopic Dermatitis recommend TCS use for flares uncontrolled by adequate skin care and moisturizers in Asian patients with AD [36]. However, TCI have similar efficacy to low-to-mid potency TCS overall [50], and may be considered as an alternative to TCS.

Two TCI were licensed since the early 2000s, namely tacrolimus and pimecrolimus. Tacrolimus ointment is available in a $0.03 \%$ formulation, approved for the treatment of moderateto-severe $\mathrm{AD}$ in patients aged $2-15$ years, and as a $0.1 \%$ formulation licensed for use in patients aged $\geq 16$ years. Pimecrolimus $1 \%$ cream is licensed for the treatment of mild-to-moderate $\mathrm{AD}$ in adults and children aged $\geq 2$ years, and in several countries pimecrolimus is also approved for infants aged $\geq 3$ months (including Thailand [44], Indonesia [49] and the Philippines [47]). When TCI are not available, TCS should be used. Where use of TCI is not limited by their availability, we recommend taking multiple factors into consideration in the selection of TCS or TCI, such as patient attitude to treatment, site of $\mathrm{AD}$ lesions, and side effects of previous steroid treatment (discussed in detail in following subsections). 
Table 1 Topical anti-inflammatory agents used in the treatment of $\mathrm{AD}$ in Asia [22, 23, 36-40]

\begin{tabular}{|c|c|c|c|}
\hline $\begin{array}{l}\text { Topical anti- } \\
\text { inflammatory agents }\end{array}$ & $\begin{array}{l}\text { Strength } \\
(\%)\end{array}$ & Formulation & Recommended usage \\
\hline \multicolumn{4}{|c|}{ Topical calcineurin inhibitors } \\
\hline Pimecrolimus & $1^{\mathrm{a}}$ & Cream & $\begin{array}{l}\text { Control of mild-to-moderate acute flares on sensitive } \\
\text { skin and other body areas } \\
\text { Intermittent use on sensitive skin and other body } \\
\text { areas }\end{array}$ \\
\hline Tacrolimus & $0.03^{\mathrm{b}}, 0.1^{\mathrm{c}}$ & Ointment & $\begin{array}{l}\text { Control of moderate-to-severe acute flares on body } \\
\text { areas other than face/flexures/other sensitive skin } \\
\text { Proactive use on non-sensitive skin }\end{array}$ \\
\hline \multicolumn{4}{|l|}{ Topical corticosteroids } \\
\hline \multicolumn{4}{|l|}{ Class 7} \\
\hline Dexamethasone & 0.1 & Cream & Control of mild acute flares on non-sensitive skin \\
\hline Hydrocortisone & $0.25,0.5,1$ & $\begin{array}{l}\text { Cream/ointment/ } \\
\text { lotion/solution }\end{array}$ & \\
\hline $\begin{array}{l}\text { Hydrocortisone } \\
\text { acetate }\end{array}$ & $0.5-1$ & Cream/ointment & \\
\hline \multicolumn{4}{|l|}{ Class 6} \\
\hline $\begin{array}{l}\text { Fluocinolone } \\
\text { acetonide }\end{array}$ & 0.01 & Cream/solution & $\begin{array}{l}\text { Control of mild-to-moderate acute flares } \\
\text { on non-sensitive skin }\end{array}$ \\
\hline Desonide & 0.05 & $\begin{array}{l}\text { Cream/gel/foam/ } \\
\text { ointment }\end{array}$ & \\
\hline $\begin{array}{l}\text { Alclometasone } \\
\text { dipropionate }\end{array}$ & 0.05 & Cream/ointment & \\
\hline \multicolumn{4}{|l|}{ Class 5} \\
\hline $\begin{array}{l}\text { Hydrocortisone } \\
\text { valerate }\end{array}$ & 0.2 & Cream/ointment & $\begin{array}{l}\text { Control of mild-to-moderate acute flares on non- } \\
\text { sensitive skin }\end{array}$ \\
\hline $\begin{array}{l}\text { Hydrocortisone } \\
\text { probutate }\end{array}$ & 0.1 & Cream & \\
\hline $\begin{array}{l}\text { Hydrocortisone } \\
\text { butyrate }\end{array}$ & 0.1 & Cream/ointment/solution & \\
\hline
\end{tabular}


Table 1 continued

\begin{tabular}{|c|c|c|c|}
\hline $\begin{array}{l}\text { Topical anti- } \\
\text { inflammatory agents }\end{array}$ & $\begin{array}{l}\text { Strength } \\
(\%)\end{array}$ & Formulation & Recommended usage \\
\hline \multicolumn{4}{|l|}{ Class 3-4 } \\
\hline $\begin{array}{l}\text { Triamcinolone } \\
\text { acetonide }\end{array}$ & 0.1 & Cream/ointment & \multirow[t]{5}{*}{$\begin{array}{l}\text { Control of mild-to-moderate acute } \\
\text { flares on non-sensitive skin }\end{array}$} \\
\hline Mometasone furoate & 0.1 & Cream & \\
\hline $\begin{array}{l}\text { Fluticasone } \\
\text { propionate }\end{array}$ & 0.05 & Cream/ointment & \\
\hline $\begin{array}{l}\text { Fluocinolone } \\
\text { acetonide }\end{array}$ & 0.025 & Cream/ointment & \\
\hline $\begin{array}{l}\text { Betamethasone } \\
\text { valerate }\end{array}$ & 0.1 & $\begin{array}{l}\text { Cream/foam/lotion/ } \\
\text { ointment }\end{array}$ & \\
\hline \multicolumn{4}{|l|}{ Class 2} \\
\hline $\begin{array}{l}\text { Triamcinolone } \\
\text { acetonide }\end{array}$ & 0.5 & Cream/ointment & \multirow{5}{*}{$\begin{array}{l}\text { Control of moderate-to-severe acute } \\
\text { flares on non-sensitive skin (limited duration of use: } \\
<2 \text { weeks) }\end{array}$} \\
\hline Mometasone furoate & 0.1 & Ointment & \\
\hline Fluocinonide & 0.05 & $\begin{array}{l}\text { Cream/gel/ } \\
\text { ointment/solution }\end{array}$ & \\
\hline $\begin{array}{l}\text { Betamethasone } \\
\text { dipropionate }\end{array}$ & 0.05 & $\begin{array}{l}\text { Cream/foam/ } \\
\text { ointment/solution }\end{array}$ & \\
\hline Amcinonide & 0.1 & Cream/lotion/ointment & \\
\hline \multicolumn{4}{|l|}{ Class 1} \\
\hline Diflorasone diacetate & 0.05 & Ointment & \multirow{2}{*}{$\begin{array}{l}\text { Control of severe acute flares on non-sensitive } \\
\text { skin (limited duration of use: }<2 \text { weeks) }\end{array}$} \\
\hline Clobetasol propionate & 0.05 & Cream/foam/ointment & \\
\hline
\end{tabular}

Table is adapted from Chow et al. [36]. Some of the agents listed in table may not be available in all Asian countries

a Infants aged 3 months to 2 years (Australia [41], Brazil [42], India [43], Indonesia [49], Israel [45], New Zealand [46], Philippines [47], Russia [48], Thailand [44] only; use in infants off-label elsewhere); children aged $\geq 2$ years, adolescents, and adults. Pimecrolimus is not available for use in Japan

b Children aged $\geq 2$ years and adolescents aged $<16$ years

c Adolescents aged $\geq 16$ years and adults

\section{Patient Attitudes to Each Treatment Option}

As mentioned above, corticophobia can compromise effective treatment with TCS because patients may fail to use their prescribed treatment or discontinue treatment prematurely to minimize steroid exposure [51-54]. While providing patients with accurate information regarding TCS may help alleviate concerns [55], TCI should also be considered in cases where patients (or parents/caregivers of pediatric patients) express concerns regarding TCS use [56]. Conversely, some patients may be reluctant to use a TCI due to perceived safety concerns, since both tacrolimus and pimecrolimus carry a black box warning for risk of malignancy (e.g., lymphoma) $[57,58]$. However, no causal relationship has been established, and as safety data accumulate, systematic reviews have not 
found evidence of increased cancer risk $[59,60]$. Indeed, the first Asian study to investigate the risk of malignancies with TCI in patients with $\mathrm{AD}$ found no association between pimecrolimus and tacrolimus use and overall development of malignancies [61]. Furthermore, a recent prospective, observational study of approximately 8000 children with AD who were treated with tacrolimus ointment for $\geq 6$ weeks observed no incidence of lymphoma over a 10 -year period [62]. The authors of the study concluded that there was no evidence to suggest that tacrolimus increased the long-term risk of cancer in children with $\mathrm{AD}$ [62]. A proactive approach by the clinician to openly discuss the content of the black box warning with the patient may help to reduce patient anxiety and subsequently help to improve TCI adherence $[26,63]$. Nevertheless, misinformation and distrust of TCI and TCS persists in Asian populations [64].

In an observational study of the efficacy and safety of pimecrolimus $1 \%$ cream in patients with $\mathrm{AD}$ who were previously treated with TCS, patient satisfaction was higher with pimecrolimus than with TCS [65]. Approximately $60 \%$ of patients had no concerns about using pimecrolimus on sensitive skin compared with $10.1 \%$ for TCS [65]. In addition, more than $77 \%$ of patients felt that pimecrolimus improved their quality of life compared with less than $43 \%$ for TCS [65]. Similarly, in a 4-year followup study of children and adult patients with $\mathrm{AD}$ treated with $0.1 \%$ tacrolimus, $75 \%$ of patients and $76 \%$ of investigators expressed high satisfaction with the treatment [66]. In studies comparing tacrolimus $0.1 \%$ and TCS, efficacy results have favored tacrolimus although comparison of their impact on quality of life is less clear-cut $[67,68]$. In a study comparing pimecrolimus $1 \%$ cream and tacrolimus $0.03 \%$ ointment in pediatric patients with $\mathrm{AD}$, although efficacy was similar between treatments, a greater proportion of patients (or caregivers, in the case of pediatric patients unable to answer questions themselves) rated pimecrolimus as very good or excellent compared with tacrolimus for several aspects, including suitability for use on sensitive facial skin; non-sticky feel; ease of application; and ease of rub-in [69]. In the hot and humid climate of South and East Asia, the propensity to sweat from excessive heat is high and can be an aggravating factor for $\mathrm{AD}$ [70]. Therefore, certain product characteristics attributed to pimecrolimus, such as its nonsticky feel and ease of rub-in, should prove to be particularly beneficial. By contrast, ointments may be more occlusive and feel more greasy, especially when used in hot and humid conditions, trapping excess heat and sweat on the skin and potentially further exacerbating the risk of $\mathrm{AD}$ flares.

\section{Site of AD Lesions}

Sensitive skin areas, such as the face, neck, and skin flexures, are at particular risk of epidermal barrier impairment and skin atrophy with TCS treatment. Therefore, TCI are useful to treat patients with $\mathrm{AD}$ affecting these areas $[14,22]$. In support of this approach, American and European guidelines for the treatment of $\mathrm{AD}$ recommend TCI, rather than TCS, as the preferred treatment for sensitive skin areas $[25,26]$.

The proactive treatment of sensitive skin areas involves long-term, low-dose intermittent topical anti-inflammatory therapy for previously affected areas with subclinical inflammation [71]. Patients experiencing frequent flares may require proactive anti-inflammatory treatment as an adjunct to continued use of emollients for maintenance treatment. Concerns regarding the side effects of TCS may be heightened if their prolonged use is required. In contrast, beneficial effects of TCI have been observed in long-term studies. Two early intervention studies of pimecrolimus (one in infants aged 3-23 months and one in children aged 2-17 years) have demonstrated a reduction in the incidence of flares with pimecrolimus compared with vehicle, as well as improved control of $\mathrm{AD}$, over a period of 12 months $[72,73]$. Furthermore, a 5-year study of 'as needed' treatment with pimecrolimus or TCS in infants with $\mathrm{AD}$ demonstrated that pimecrolimus had a similar efficacy to TCS and raised no safety concerns [74]. A non-comparative study of intermittent or continuous application of tacrolimus $0.1 \%$ ointment for up to 4 years (patients $\geq 2$ years old) demonstrated sustained efficacy and a safety profile comparable with 
those reported for shorter studies [66]. Longterm proactive treatment of AD in children with either pimecrolimus $1 \%$ cream (16-week study [75]) or tacrolimus $0.03 \%$ ointment (40-week study [76] and two 12-month assessments $[77,78])$ has been found to delay flares and prevent relapses. Therefore, patients requiring proactive anti-inflammatory treatment and those for whom prolonged TCS use is not desired, may benefit from a TCI.

The authors of a recent systematic review of long-term efficacy and safety of both TCS and TCI for pediatric use concluded that TCI should be the standard-of-care maintenance therapy, with low-to-mid potency TCS used intermittently to control flares [60]. Twice-weekly application of TCI (rather than daily application) and regular emollient use is recommended for long-term maintenance therapy [22].

\section{Side Effects of Previous Steroid Therapy}

Patients who have experienced steroid-induced side effects when using corticosteroids for other pathologies are also candidates for treatment with TCI $[25,56]$.

\section{Role of TCI}

The use of tacrolimus has been evaluated in clinical trials involving Asian patients. Pooled analysis of data from several Asian studies found that the efficacy and safety of tacrolimus use in the Asian population was similar to that seen in European and US studies [79]. Similarly, ethnic origin has been found to have no effect on the efficacy of pimecrolimus, based on a pooled analysis of three pediatric studies comparing Caucasian and non-Caucasian (including Asian) subgroups [80]. In view of these findings, where results from studies not conducted specifically in Asian patients are reported in this paper, we believe that the results can be extrapolated to guide treatment practice in South and East Asia.

The most common side effects with TCI therapy are transient local application site reactions, including erythema, pruritus, and stinging/burning sensations. In a comparative study of TCI use by patients aged $2-17$ years, application site reactions were less common and of shorter duration with pimecrolimus than with tacrolimus $[26,69]$. At Day 4 , the incidence of erythema/irritation with pimecrolimus was six out of $71(8 \%)$ patients compared with 13 out of $70(19 \%)$ patients with tacrolimus ( $p=0.039$ ) [69]. Furthermore, only six out of 71 (8\%) patients experienced itching with pimecrolimus use in comparison with 14 out of 70 (20\%) patients using tacrolimus $(p=0.073)$ [69]. Among those who experienced erythema/ irritation, it was found that no patients using pimecrolimus experienced these symptoms for longer than $30 \mathrm{~min}$, compared with 11 out of 13 $(85 \%)$ patients applying tacrolimus $(p<0.001)$ [69]. Local burning may also occur less frequently in patients using pimecrolimus $1 \%$ cream, with $7.4 \%$ of pediatric patients and $10.4 \%$ of adults experiencing this side effect after applying the cream, compared with up to $36 \%$ of pediatric patients and $47 \%$ of adult patients applying tacrolimus ointment [81].

The potential for application site reactions should be discussed with patients (or parents/caregivers of pediatric patients) prior to the initiation of TCI treatment, and reassurance given that such reactions are transient. Offering this reassurance may reduce the likelihood of premature discontinuation if unexpected burning or stinging sensations occur. As discussed above, there remains no evidence for any causal relationship between TCI and malignancies, such as lymphoma [82].

\section{Use of TCI on Sensitive Skin Areas}

Those parts of the body where the skin is thinner than other areas are disproportionately affected by $\mathrm{AD}$ and therefore require special consideration in relation to $\mathrm{AD}$ management. TCS should be used with caution in sensitive skin areas, particularly in the peri-ocular region [22]. Despite TCS often being less expensive than TCI in most South and East Asian countries, TCI may be a more suitable treatment option than TCS for two important reasons, namely, a greater selectivity in targeting cells involved in the inflammatory response and a lower potential for transcutaneous resorption, as discussed in the following subsections 


\section{TCI Have Greater Selectivity than TCS in Terms of Targeting Cells Involved in the Inflammatory Response at Sites Affected by $A D$}

Preclinical studies have shown that, unlike TCS and tacrolimus [83, 84], pimecrolimus does not affect epidermal Langerhans cells, which have an important role in cutaneous immunological responses $[85,86]$. These findings have also been confirmed in a clinical study [87]. Analysis of skin biopsies from patients treated with pimecrolimus or betamethasone valerate (BMV) showed that pimecrolimus depleted $\mathrm{T}$ cells at sites of inflammation via the induction of apoptosis, but spared Langerhans cells, whereas BMV application depleted both Langerhans cells and $\mathrm{T}$ cells [87]. Both treatments also depleted dendritic epidermal cells in this study [87]. Tacrolimus depletes inflammatory dendritic epidermal cells with greater selectivity than TCS but also affects the immunophenotype of Langerhans cells [83, 84]. Pimecrolimus therefore has a more favorable balance of antiinflammatory versus immunosuppressive activity compared with tacrolimus and TCS [88].

\section{TCI Have Lower Potential for Transcutaneous Resorption than TCS}

The beneficial property of TCI in terms of its lower potential for trancutaneous resporption is a particularly important consideration in thin skin areas because it reduces systemic exposure to topically applied medication. A comparison of the TCI revealed that pimecrolimus permeates the skin to a lesser extent than tacrolimus due to its greater lipophilicity and higher binding affinity for skin proteins [89, 90]. When pimecrolimus was compared with tacrolimus, the permeation of pimecrolimus through human skin was consistently lower by factors of 9-10, and in comparison with TCS the permeation was lower by factors of 70-110 [89]. While pimecrolimus possesses comparatively low exposure, it should be noted that patients treated with the highest concentration of tacrolimus $(0.1 \%)$ experience low systemic exposure [91], and both TCI can be considered to be appropriate agents for situations requiring low permeability.
Given the mechanistic differences described above, we recommend pimecrolimus as the first-choice TCI for sensitive skin areas in mildto-moderate disease; studies providing clinical evidence to support its use in special situations, such as facial $\mathrm{AD}$, are summarized in Table 2 $[69,74,92-95]$. As pimecrolimus is not indicated for severe $\mathrm{AD}$, we recommend tacrolimus for sensitive skin areas beyond moderate disease, as tacrolimus is recommended for use in moderate and severe disease; short-term treatment with TCS may also be appropriate, with a subsequent switch to a TCI when inflammation subsides. For AD in other parts of the body, the selection of a TCI can be determined by physician and patient preference.

\section{Other Treatments}

Crisaborole ointment, a phosphodiesterase-4 (PDE4) inhibitor, provides a novel steroid-sparing alternative to TCS or TCI for topical treatment of mild-to-moderate $\mathrm{AD}$ in patients aged $\geq 2$ years [96]. However, it is currently only licensed in the USA and Canada, and its efficacy and safety has not been investigated in Asian patients; therefore its potential role in the management of $\mathrm{AD}$ in South and East Asia remains to be seen.

There have been many novel developments for the treatment of moderate-to-severe $\mathrm{AD}$ (e.g., biologics, such as dupilumab, and small molecules, including Janus kinase inhibitors and aryl hydrocarbon receptor-modifying agents) [97, 98].

\section{CONCLUSIONS}

Atopic dermatitis is a prevalent condition in Asia, particularly in urban areas, and effective treatment strategies are needed. We recommend pimecrolimus as the treatment of choice for mild-to-moderate $\mathrm{AD}$ affecting sensitive skin areas, with tacrolimus considered for moderate and severe cases. For other body locations, we recommend either pimecrolimus or tacrolimus, which are indicated for mild-to-moderate and moderate-to-severe $\mathrm{AD}$, respectively. 
Table 2 Evidence for efficacy of pimecrolimus in thin skin areas

\begin{tabular}{|c|c|c|c|c|}
\hline $\begin{array}{l}\text { First author of study, } \\
\text { year, reference }\end{array}$ & Age of patients & $n$ & $\begin{array}{l}\text { Body } \\
\text { area }\end{array}$ & Outcome \\
\hline $\begin{array}{l}\text { Sigurgeirsson B, } 2015 \\
\quad \text { (PETITE Study) [74] }\end{array}$ & $\begin{array}{l}\text { Infants } \\
(3-12 \text { months }) \\
\text { followed to age } \\
5-6 \text { years }\end{array}$ & 2418 & $\begin{array}{r}\text { Facial } \\
\mathrm{AD}\end{array}$ & $\begin{array}{l}\text { Treatment success (facial IGA score } 0 \text { or } 1 \text { ) achieved } \\
\text { by } 61.0 \text { and } 61.8 \% \text { of patients in pimecrolimus and } \\
\text { TCS groups, respectively, after } 3 \text { weeks of treatment; } \\
96.6 \text { and } 97.2 \% \text { of patients, respectively, had IGA } \\
\text { score } 0 \text { or } 1 \text { at end of } 5 \text {-year study }\end{array}$ \\
\hline Hoeger PH, 2009 [92] & $2-11$ years & 200 & $\begin{array}{r}\text { Facial } \\
\mathrm{AD}\end{array}$ & $\begin{array}{l}\text { IGA score } 0 \text { or } 1 \text { in } 74.5 \% \text { of patients in pimecrolimus } \\
\text { group, vs. } 51.0 \% \text { in vehicle group }(p<0.001) \text { at } \\
6 \text { weeks }\end{array}$ \\
\hline Zuberbier T, 2008 [93] & $2-17$ years & 140 & $\begin{array}{r}\text { Facial } \\
\mathrm{AD}\end{array}$ & $\begin{array}{l}\text { Pimecrolimus delayed time to first flare ( } 138 \text { vs. } \\
68 \text { days; } p=0.01 \text { ) and reduced need for TCS ( } 11.7 \\
\text { vs. } 20.7 \% ; p=0.0024) \text { compared with vehicle } \\
50 \% \text { of pimecrolimus-treated patients free from facial } \\
\text { AD flare over } 24 \text { weeks, vs. } 37.5 \% \text { in vehicle group } \\
(p=0.012)\end{array}$ \\
\hline Kempers S, 2004 [69] & $2-17$ years & 141 & $\begin{array}{l}\text { Head } \\
\text { and } \\
\text { neck }\end{array}$ & $\begin{array}{l}53.7 \% \text { reduction in head/neck BSA affected with } \\
\text { pimecrolimus vs. } 34.9 \% \text { reduction with tacrolimus }\end{array}$ \\
\hline $\begin{array}{l}\text { Lubbe J, } 2006 \\
\text { (Prospective study in } \\
\text { clinical practice) [94] }\end{array}$ & 3 months to 81 years & 947 & $\begin{array}{r}\text { Facial } \\
\mathrm{AD}\end{array}$ & $\begin{array}{l}65-80 \% \text { of patients (varying across age groups) } \\
\text { achieved facial IGA } 0 \text { or } 1 \text { after } 24 \text { weeks of } \\
\text { pimecrolimus treatment } \\
\text { Improvement more pronounced for facial IGA than } \\
\text { whole body IGA ( } 43-54 \% \text { with IGA } 0 \text { or } 1 \text { at } \\
24 \text { weeks) }\end{array}$ \\
\hline \multirow[t]{3}{*}{ Murrell DF, 2007 [95] } & $\begin{array}{l}\geq 12 \text { years } \\
\text { (adolescent/adult) }\end{array}$ & 200 & $\begin{array}{r}\text { Facial } \\
\mathrm{AD}\end{array}$ & $\begin{array}{l}\text { Facial IGA } 0 \text { or } 1 \text { in } 46.5 \% \text { of pimecrolimus-treated } \\
\text { patients vs. } 16.2 \% \text { in vehicle group }(p<0.001) \text { at } \\
6 \text { weeks }\end{array}$ \\
\hline & & & $\begin{array}{l}\text { Head } \\
\text { and } \\
\text { neck }\end{array}$ & $\begin{array}{l}\geq 60 \% \text { change in head } / \text { neck EASI score in } 50.5 \% \text { of } \\
\text { pimecrolimus-treated patients vs. } 18.2 \% \text { in vehicle } \\
\text { group }(p<0.001) \text { at } 6 \text { weeks }\end{array}$ \\
\hline & & & Eyelids & $\begin{array}{l}44.6 \% \text { of patients in pimecrolimus group vs } 19.2 \% \text { in } \\
\text { vehicle group }(p<0.001) \text { clear of eyelid dermatitis } \\
\text { at } 6 \text { weeks }\end{array}$ \\
\hline
\end{tabular}

$A D$ Atopic dermatitis, $B S A$ body surface area, EASI Eczema Area and Severity Index, $I G A$ Investigator Global Assessment (Score $0=$ clear; 1 = almost clear), TCS topical corticosteroids 
We also recommend a proactive maintenance treatment strategy involving the application of a TCI and emollients to previously affected areas. This maintenance therapy reduces the likelihood of disease flares occurring. All patients with $\mathrm{AD}$ should be encouraged to undertake general skin care measures, including the liberal and regular use of emollients on affected skin.

The algorithm presented here is intended to simplify the topical treatment of mild-to-moderate $\mathrm{AD}$ in daily practice in South and East Asian countries.

\section{ACKNOWLEDGEMENTS}

Funding. The writing/editorial support and the Journal's Rapid Service Fee were funded by Meda Pharma S.p.A., a Viatris company.

Authorship. All named authors meet the International Committee of Medical Journal Editors (ICMJE) criteria for authorship for this article, take responsibility for the integrity of the work as a whole, and have given their approval for this version to be published.

Medical Writing and Editorial Assistance. Medical writing assistance in the preparation of this manuscript was provided by Samantha Stanbury (a medical writer contracted to Ashfield Healthcare Communications Group Ltd) and Jane Murphy (CircleScience, an Ashfield Company, part of UDG Healthcare plc), and funded by Meda Pharma S.p.A., a Viatris company.

Disclosures. David Luk has received speaker honoraria from Menarini. Kam Lun Hon has participated in clinical trials involving products by Galderma, Kao, LEO Pharma, Hoe Pharmaceuticals, GlaxoSmithKline, and Bioderma. Maria Victoria Dizon has participated as an investigator in clinical trials sponsored by Johnson \& Johnson; has received consultancy/ speaker honoraria from Johnson \& Johnson, Menarini, LEO Pharma, Bioderma, Galderma, and Glenmark; and serves on the advisory board of Johnson \& Johnson Global and the Menarini advisory board of Asia. Mark Jean-Aan Koh has participated in clinical trials as principal or coinvestigator sponsored by Galderma and Hyphens; and has received speaker honoraria from Galderma, Hyphens, LEO Pharma, Good Pharma, GSK, and Bioderma. Nisha Suyien Chandran has received consultancy/speaker honoraria from LEO Pharma, GlaxoSmithKline, Eli Lilly, Galderma, Menarini, and Janssen. Siriwan Wananukul has received research grants from Beiersdorf and Menarini; and has received speaker honoraria from Astellas, Beiersdorf, Bioderma, Galderma, Hoe Pharmaceuticals, Janssen-Cilag, Johnson \& Johnson, La Roche Posay, LEO Pharma, Viatris, and Menarini. Thomas Luger has participated as Principal Investigator in clinical trials and on advisory boards and has given lectures sponsored by Novartis, Lilly, La Roche Posay, Pfizer, Janssen, and Sanofi; has received consultancy/speaker honoraria from Novartis, Abbvie, Galderma, La Roche Posay, Viatris, Janssen, and Sanofi; has acted as scientific Advisory Board member for Abbvie, Celgene, La Roche Posay, Janssen, Pfizer, Menlo, Viatris, Galderma, Symrise, and Lilly; and has received research grants from Celgene, Janssen-Cilag, Leo, Viatris, and Pfizer. Kin-Fon Leong, Yong Kwang Tay, and Susheera Chatproedprai declare that they have no conflict of interest.

Compliance with Ethics Guidelines. This article is based on previously conducted studies and does not contain any studies with human participants or animals performed by any of the authors.

Data Availability. Data sharing is not applicable to this article as no datasets were generated or analysed during the current study.

Open Access. This article is licensed under a Creative Commons Attribution-NonCommercial 4.0 International License, which permits any non-commercial use, sharing, adaptation, distribution and reproduction in any medium or format, as long as you give appropriate credit to the original author(s) and the source, provide a link to the Creative Commons licence, and 
indicate if changes were made. The images or other third party material in this article are included in the article's Creative Commons licence, unless indicated otherwise in a credit line to the material. If material is not included in the article's Creative Commons licence and your intended use is not permitted by statutory regulation or exceeds the permitted use, you will need to obtain permission directly from the copyright holder. To view a copy of this licence, visit http://creativecommons.org/licenses/by$\mathrm{nc} / 4.0 /$.

\section{REFERENCES}

1. Watson W, Kapur S. Atopic dermatitis. Allergy Asthma Clin Immunol. 2011;7(Suppl 1):S4.

2. Weidinger S, Novak N. Atopic dermatitis. Lancet. 2016;387:1109-22.

3. Noda S, Suarez-Farinas M, Ungar B, et al. The Asian atopic dermatitis phenotype combines features of atopic dermatitis and psoriasis with increased TH17 polarization. J Allergy Clin Immunol. 2015;136: 1254-64.

4. Cheok S, Yee F, Song Ma JY, et al. Prevalence and descriptive epidemiology of atopic dermatitis and its impact on quality of life in Singapore. Br J Dermatol. 2018;178:276-7.

5. Goh YY, Keshavarzi F, Chew YL. Prevalence of atopic dermatitis and pattern of drug therapy in malaysian children. Dermatitis. 2018;29:151-61.

6. Yu JS, Lee CJ, Lee HS, et al. Prevalence of atopic dermatitis in Korea: analysis by using national statistics. J Korean Med Sci. 2012;27:681-5.

7. Deckers IA, McLean S, Linssen S, Mommers M, van Schayck CP, Sheikh A. Investigating international time trends in the incidence and prevalence of atopic eczema 1990-2010: a systematic review of epidemiological studies. PLoS ONE. 2012;7:e39803.

8. Tay YK, Kong KH, Khoo L, Goh CL, Giam YC. The prevalence and descriptive epidemiology of atopic dermatitis in Singapore school children. Br J Dermatol. 2002;146:101-6.

9. Kabashima K, Otsuka A, Nomura T. Linking air pollution to atopic dermatitis. Nat Immunol. 2016;18:5-6.
10. Hidaka T, Ogawa E, Kobayashi EH, et al. The aryl hydrocarbon receptor AhR links atopic dermatitis and air pollution via induction of the neurotrophic factor artemin. Nat Immunol. 2017;18:64-73.

11. Chen H, Common JE, Haines RL, et al. Wide spectrum of filaggrin-null mutations in atopic dermatitis highlights differences between Singaporean Chinese and European populations. Br J Dermatol. 2011;165:106-14.

12. Meng L, Wang L, Tang $\mathrm{H}$, et al. Filaggrin gene mutation c.3321delA is associated with various clinical features of atopic dermatitis in the Chinese Han population. PLoS ONE. 2014;9:e98235.

13. Chan YC, Tay YK, Sugito TL, et al. A study on the knowledge, attitudes and practices of Southeast Asian dermatologists in the management of atopic dermatitis. Ann Acad Med Singapore. 2006;35: 794-803.

14. Leung TN, Hon KL. Eczema therapeutics in children: what do the clinical trials say? Hong Kong Med J. 2015;21:251-60.

15. Chen HY, Lin YH, Su IH, Chen YC, Yang SH, Chen JL. Investigation on Chinese herbal medicine for primary dysmenorrhea: implication from a nationwide prescription database in Taiwan. Complement Ther Med. 2014;22:116-25.

16. Zhu Y, Shi H, Wang Q et al. Association between nine types of TCM constitution and five chronic diseases: a correspondence analysis based on a sample of 2,660 participants. Evid Based Complement Alternat Med. 2017;2017:9439682.

17. Hon KL, Leung AKC, Leung TNH, Lee VWY. Complementary, alternative and integrative medicine for childhood atopic dermatitis. Recent Pat Inflamm Allergy Drug Discov. 2017;11:114-24.

18. Draelos ZD. Use of topical corticosteroids and topical calcineurin inhibitors for the treatment of atopic dermatitis in thin and sensitive skin areas. Curr Med Res Opin. 2008;24:985-94.

19. Mueller SM, Itin P, Vogt DR, et al. Assessment of "corticophobia" as an indicator of non-adherence to topical corticosteroids: a pilot study. J Dermatolog Treat. 2017;28:104-11.

20. Ring J, Alomar A, Bieber $\mathrm{T}$, et al. Guidelines for treatment of atopic eczema (atopic dermatitis) Part II. J Eur Acad Dermatol Venereol. 2012a;26: 1176-93.

21. Sidbury R, Tom WL, Bergman JN, et al. Guidelines of care for the management of atopic dermatitis: section 4. Prevention of disease flares and use of 
adjunctive therapies and approaches. J Am Acad Dermatol. 2014;71:1218-33.

22. Tay YK, Chan YC, Chandran NS, et al. Guidelines for the management of atopic dermatitis in Singapore. Ann Acad Med Singapore. 2016;45:439-50.

23. Leung TNH, Chow CM, Chow MPY, et al. Clinical guidelines on management of atopic dermatitis in children. Hong Kong J Paediatr. 2013;18:96-104.

24. Ring J, Alomar A, Bieber T, et al. Guidelines for treatment of atopic eczema (atopic dermatitis) part I. J Eur Acad Dermatol Venereol. 2012;26:1045-60.

25. Sidbury R, Davis DM, Cohen DE, et al. Guidelines of care for the management of atopic dermatitis: section 3. Management and treatment with phototherapy and systemic agents. J Am Acad Dermatol. 2014;71:327-49.

26. Wollenberg A, Barbarot S, Bieber T, et al. Consensus-based European guidelines for treatment of atopic eczema (atopic dermatitis) in adults and children: part I. J Eur Acad Dermatol Venereol. 2018;32:657-82.

27. Reda AM, Elgendi A, Ebraheem AI, et al. A practical algorithm for topical treatment of atopic dermatitis in the Middle East emphasizing the importance of sensitive skin areas. J Dermatolog Treat. 2019;30: 366-73.

28. Eichenfield LF, Boguniewicz M, Simpson EL, et al. Translating atopic dermatitis management guidelines into practice for primary care providers. Pediatrics. 2015;136:554-65.

29. Werfel T, Ballmer-Weber B, Eigenmann PA, et al. Eczematous reactions to food in atopic eczema: position paper of the EAACI and GA2LEN. Allergy. 2007;62:723-8.

30. Hon KL, Leung AK, Barankin B. Barrier repair therapy in atopic dermatitis: an overview. Am J Clin Dermatol. 2013;14:389-99.

31. Hon KL, Kung JSC, Ng WGG, Leung TF. Emollient treatment of atopic dermatitis: latest evidence and clinical considerations. Drugs Context. 2018;7: 212530 .

32. Saeki H. Management of atopic dermatitis in Japan. J Nippon Med School. 2017;84:2-11.

33. Kong $\mathrm{HH}$, Oh J, Deming C, et al. Temporal shifts in the skin microbiome associated with disease flares and treatment in children with atopic dermatitis. Genome Res. 2012;22:850-9.
34. Williams MR, Gallo RL. Evidence that human skin microbiome dysbiosis promotes atopic dermatitis. J Invest Dermatol. 2017;137:2460-1.

35. Hon KL, Tsang KY, Kung JS, Leung TF, Lam CW, Wong CK. Clinical Signs, staphylococcus and atopic eczema-related seromarkers. Molecules. 2017;22(2):291.

36. Chow S, Seow CS, Dizon MV, et al. A clinician's reference guide for the management of atopic dermatitis in Asians. Asia Pac Allergy. 2018;8:e41.

37. Katayama I, Aihara M, Ohya Y, et al. Japanese guidelines for atopic dermatitis 2017. Allergol Int. 2017;66:230-47.

38. Nankervis H, Thomas KS, Delamere FM, Barbarot $\mathrm{S}$, Rogers NK, Williams HC. Scoping systematic review of treatments for eczema. Programme Grants Appl Res. 2016;4. https://doi.org/10.3310/pgfar04070.

39. Saeki H, Nakahara T, Tanaka A, et al. Clinical practice guidelines for the management of atopic dermatitis 2016. J Dermatol. 2016;43:1117-45.

40. Kim JE, Kim HJ, Lew BL, et al. Consensus guidelines for the treatment of atopic dermatitis in Korea (Part I): general management and topical treatment. Ann Dermatol. 2015;27:563-77.

41. Mylan. Elidel 1\% Summary of Product Characteristics (Australia). Mylan. May 2018. https://protecteu.mimecast.com/s/IjCnCXm4irwMxyI6bnKd?do main=medicines.org.au. https://medicines.org. au/i/view/gopelidePI. Accessed Jan 2020.

42. Mylan. Elidel 1\% Summary of Product Characteristics (Brazil). Mylan. November 2018.

43. Mylan. Elidel 1\% Summary of Product Characteristics (India). Mylan. May 2018.

44. Mylan. Elidel 1\% Summary of Product Characteristics (Thailand). Mylan. April 2008.

45. Mylan. Elidel 1\% Prescribing Information (Israel). Mylan. September 2009. https://protect-eu. mimecast.com/s/JsAwC6LZTYA26WHpqAbt?doma in=data.health.gov.il. https://data.health.gov.il/dr ugs/alonim/Elidel_dr_1328699572985.pdf. Accessed Jan 2020

46. Mylan. Elidel 1\% Summary of Product Characteristics (New Zealand). Mylan. April 2018.

47. Mylan. Elidel 1\% Summary of Product Characteristics (Philippines). Mylan. April 2017.

48. Mylan. Elidel 1\% Prescribing Information (Russia). Mylan. https://protect-eu.mimecast.com/s/buTRC 7N4T1AEAKt8ReNj?domain=diateza.net. https:// 
diateza.net/upload/doc/elidel.pdf. Accessed Jan 2020

49. Mylan. Elidel 1\% Summary of Product Characteristics (Indonesia). Mylan. April 2008.

50. Broeders JA, Ahmed Ali U, Fischer G. Systematic review and meta-analysis of randomized clinical trials (RCTs) comparing topical calcineurin inhibitors with topical corticosteroids for atopic dermatitis: a 15-year experience. J Am Acad Dermatol. 2016;75(410-9):e3.

51. Li AW, Yin ES, Antaya RJ. Topical corticosteroid phobia in atopic dermatitis: a systematic review. JAMA Dermatol. 2017;153:1036-42.

52. Lee JY, Her Y, Kim CW, Kim SS. Topical corticosteroid phobia among parents of children with atopic eczema in Korea. Ann Dermatol. 2015;27: 499-506.

53. Kojima R, Fujiwara T, Matsuda A, et al. Factors associated with steroid phobia in caregivers of children with atopic dermatitis. Pediatr Dermatol. 2013;30:29-35.

54. Hon KL, Tsang YC, Pong NH, et al. Correlations among steroid fear, acceptability, usage frequency, quality of life and disease severity in childhood eczema. J Dermatolog Treat. 2015;26:418-25.

55. Muller SM, Tomaschett D, Euler S, Vogt DR, Herzog $\mathrm{L}$, Itin P. Topical corticosteroid concerns in dermatological outpatients: a cross-sectional and interventional study. Dermatology. 2016;232: 444-52.

56. Hussain Z, Sahudin S, Thu HE, Shuid AN, Bukhari $\mathrm{SN}$, Kumolosasi E. Recent advances in pharmacotherapeutic paradigm of mild to recalcitrant atopic dermatitis. Crit Rev Ther Drug Carrier Syst. 2016;33:213-63.

57. Valeant Pharmaceuticals. Elidel highlights of prescribing information. Valeant Pharmaceuticals. 2017. https://www.accessdata.fda.gov/drugsatfda docs/label/2014/021302s018lbl.pdf. Accessed March 2020.

58. LEO Pharma. Protopic (tacrolimus) prescribing information. LEO Pharma revised: 02/2019. Astellas Pharma. 2019. https://www.protopic.com/. Accessed Mar 2020

59. Siegfried EC, Jaworski JC, Hebert AA. Topical calcineurin inhibitors and lymphoma risk: evidence update with implications for daily practice. Am J Clin Dermatol. 2013;14:163-78.

60. Siegfried EC, Jaworski JC, Kaiser JD, Hebert AA. Systematic review of published trials: long-term safety of topical corticosteroids and topical calcineurin inhibitors in pediatric patients with atopic dermatitis. BMC Pediatr. 2016;16:75.

61. Cai SC, Li W, Tian EA, Allen JC, Tey HL. Topical calcineurin inhibitors in eczema and cancer association: a cohort study. J Dermatolog Treat. 2016;27:531-7.

62. Paller AS, Fölster-Holst R, Chen SC, et al. No evidence of increased cancer incidence in children using topical tacrolimus for atopic dermatitis. J Am Acad Dermatol. 2020;83:375-81.

63. Eichenfield LF, Tom WL, Berger TG, et al. Guidelines of care for the management of atopic dermatitis: section 2. Management and treatment of atopic dermatitis with topical therapies. J Am Acad Dermatol. 2014;71:116-32.

64. Hon KL, Leong KF, Leung TN, Leung AK. Dismissing the fallacies of childhood eczema management: case scenarios and an overview of best practices. Drugs Context. 2018;7:212547.

65. Gollnick H, Luger T, Freytag S, Brautigam M, group Ss. StabiEL: stabilization of skin condition with Elidel—a patients' satisfaction observational study addressing the treatment, with pimecrolimus cream, of atopic dermatitis pretreated with topical corticosteroid. J Eur Acad Dermatol Venereol. 2008;22:1319-25.

66. Reitamo S, Rustin M, Harper J, et al. A 4-year followup study of atopic dermatitis therapy with $0.1 \%$ tacrolimus ointment in children and adult patients. Br J Dermatol. 2008;159:942-51.

67. Langa Y, Van der Merwe E. Atopic dermatitis: tacrolimus vs. topical corticosteroid use. South Afri Fam Pract. 2011;53:340-6.

68. Svensson A, Chambers C, Gånemo A, Mitchell SA. A systematic review of tacrolimus ointment compared with corticosteroids in the treatment of atopic dermatitis. Curr Med Res Opin. 2011;27: 1395-406.

69. Kempers S, Boguniewicz M, Carter E, et al. A randomized investigator-blinded study comparing pimecrolimus cream $1 \%$ with tacrolimus ointment $0.03 \%$ in the treatment of pediatric patients with moderate atopic dermatitis. J Am Acad Dermatol. 2004;51:515-25.

70. Ee S, Tay YK, Chu CY, Hon KLE, Leong KF, Wananukul S. A study on the knowledge, attitudes, and practices of Asian dermatologists in the management of atopic dermatitis. Dermatol Sin. 2020;38: 67-80. 
71. Wollenberg A, Reitamo S, Girolomoni G, et al. Proactive treatment of atopic dermatitis in adults with $0.1 \%$ tacrolimus ointment. Allergy. 2008;63: 742-50.

72. Kapp A, Papp K, Bingham A, et al. Long-term management of atopic dermatitis in infants with topical pimecrolimus, a nonsteroid anti-inflammatory drug. J Allergy Clin Immunol. 2002;110: 277-84.

73. Wahn U, Bos JD, Goodfield M, et al. Efficacy and safety of pimecrolimus cream in the long-term management of atopic dermatitis in children. Pediatrics. 2002;110:e2.

74. Sigurgeirsson B, Boznanski A, Todd G, et al. Safety and efficacy of pimecrolimus in atopic dermatitis: a 5-year randomized trial. Pediatrics. 2015;135: 597-606.

75. Ruer-Mulard M, Aberer W, Gunstone A, et al. Twicedaily versus once-daily applications of pimecrolimus cream $1 \%$ for the prevention of disease relapse in pediatric patients with atopic dermatitis. Pediatr Dermatol. 2009;26:551-8.

76. Paller AS, Eichenfield LF, Kirsner RS, Shull T, Jaracz E, Simpson EL. Three times weekly tacrolimus ointment reduces relapse in stabilized atopic dermatitis: a new paradigm for use. Pediatrics. 2008;122:e1210-8.

77. Reitamo S, Allsopp R. Treatment with twice-weekly tacrolimus ointment in patients with moderate to severe atopic dermatitis: results from two randomized, multicentre, comparative studies. J Dermatolog Treat. 2010;21:34-44.

78. Thaci D, Reitamo S, Gonzalez Ensenat MA, et al. Proactive disease management with $0.03 \%$ tacrolimus ointment for children with atopic dermatitis: results of a randomized, multicentre, comparative study. Br J Dermatol. 2008;159:1348-56.

79. Kim KH, Kono T. Overview of efficacy and safety of tacrolimus ointment in patients with atopic dermatitis in Asia and other areas. Int J Dermatol. 2011;50:1153-61.

80. Eichenfield LF, Lucky AW, Langley RG, et al. Use of pimecrolimus cream 1\% (Elidel) in the treatment of atopic dermatitis in infants and children: the effects of ethnic origin and baseline disease severity on treatment outcome. Int J Dermatol. 2005;44:70-5.

81. Lynde C, Barber K, Claveau J, et al. Canadian practical guide for the treatment and management of atopic dermatitis. J Cutan Med Surg. 2005;8(Suppl 5):1-9.
82. Luger T, Boguniewicz M, Carr W, et al. Pimecrolimus in atopic dermatitis: consensus on safety and the need to allow use in infants. Pediatr Allergy Immunol. 2015;26:306-15.

83. Schuller E, Oppel T, Bornhovd E, Wetzel S, Wollenberg A. Tacrolimus ointment causes inflammatory dendritic epidermal cell depletion but no Langerhans cell apoptosis in patients with atopic dermatitis. J Allergy Clin Immunol. 2004;114: 137-43.

84. Panhans-Gross A, Novak N, Kraft S, Bieber T. Human epidermal Langerhans' cells are targets for the immunosuppressive macrolide tacrolimus (FK506). J Allergy Clin Immunol. 2001;107:345-52.

85. Hoetzenecker W, Meingassner JG, Ecker R, Stingl G, Stuetz A, Elbe-Burger A. Corticosteroids but not pimecrolimus affect viability, maturation and immune function of murine epidermal Langerhans cells. J Invest Dermatol. 2004;122:673-84.

86. Meingassner JG, Kowalsky E, Schwendinger H, ElbeBurger A, Stutz A. Pimecrolimus does not affect Langerhans cells in murine epidermis. Br J Dermatol. 2003;149:853-7.

87. Hoetzenecker W, Ecker R, Kopp T, Stuetz A, Stingl $G$, Elbe-Burger A. Pimecrolimus leads to an apoptosis-induced depletion of $\mathrm{T}$ cells but not Langerhans cells in patients with atopic dermatitis. J Allergy Clin Immunol. 2005;115:1276-83.

88. Grassberger M, Steinhoff M, Schneider D, Luger TA. Pimecrolimus-an anti-inflammatory drug targeting the skin. Exp Dermatol. 2004;13:721-30.

89. Billich A, Aschauer H, Aszodi A, Stuetz A. Percutaneous absorption of drugs used in atopic eczema: pimecrolimus permeates less through skin than corticosteroids and tacrolimus. Int $\mathrm{J}$ Pharm. 2004;269:29-35.

90. Weiss HM, Fresneau M, Moenius T, Stuetz A, Billich A. Binding of pimecrolimus and tacrolimus to skin and plasma proteins: implications for systemic exposure after topical application. Drug Metab Dispos. 2008;36:1812-8.

91. Harper J, Smith C, Rubins A, et al. A multicenter study of the pharmacokinetics of tacrolimus ointment after first and repeated application to children with atopic dermatitis. J Invest Dermatol. 2005;124: 695-9.

92. Hoeger PH, Lee KH, Jautova J, et al. The treatment of facial atopic dermatitis in children who are intolerant of, or dependent on, topical corticosteroids: a randomized, controlled clinical trial. $\mathrm{Br} \mathrm{J}$ Dermatol. 2009;160:415-22. 
93. Zuberbier T, Brautigam M. Long-term management of facial atopic eczema with pimecrolimus cream $1 \%$ in paediatric patients with mild to moderate disease. J Eur Acad Dermatol Venereol. 2008;22: 718-21.

94. Lubbe J, Friedlander SF, Cribier B, et al. Safety, efficacy, and dosage of $1 \%$ pimecrolimus cream for the treatment of atopic dermatitis in daily practice. Am J Clin Dermatol. 2006;7:121-31.

95. Murrell DF, Calvieri S, Ortonne JP, et al. A randomized controlled trial of pimecrolimus cream $1 \%$ in adolescents and adults with head and neck atopic dermatitis and intolerant of, or dependent on, topical corticosteroids. Br J Dermatol. 2007;157: 954-9.

96. Zane LT, Chanda S, Jarnagin K, Nelson DB, Spelman L, Gold LS. Crisaborole and its potential role in treating atopic dermatitis: overview of early clinical studies. Immunotherapy. 2016;8:853-66.

97. Hon KL, Leung AKC, Leung TNH, Lee VWY. Investigational drugs for atopic dermatitis. Expert Opin Investig Drugs. 2018;27:637-47.

98. Suga H, Sato S. Novel topical and systemic therapies in atopic dermatitis. Immunol Med. 2019;42:84-93. 